\title{
LIST PASTERSKI EPISKOPATU POLSKI O NOWYM RYTUALE
}

„Czyż nie trzeba było, aby Chrystus cierpiał i tak wszedł do swojej chwały" (Łk 24, 26). Przez Swoją śmierć na krzyżu Jezus Chrystus uwolnił nas z niewoli grzechu i dał nam moc, abyśmy się stali dziećmi Bożymi. Przez Swoje święte zmartwychwstanie dał nam zadatek nowego życia i chwaly niebieskiej. W Wielką noc Zmartwychwstania Pańskiego śpiewa Kośc ół: „Oto noc, która wierzących w Chrystusa uwalnia od zepsucia świata i ciemności grzechów, przywraca do łaski i gromadzi w społeczności świętych".

Owoce Odkupienia otrzymujemy przede wszystkim wa sakramentach świętych, które są czynnościami samego Chrystusa żyjącego nieustannie w Kościele. Przez nie Zbawiciel obdarza nas życiem nadprzyrodzonym i rozwija je. Pan Jezus sprawuje sakramenty święte w kościele i przez. Kościół. Na mocy władzy danej przez Chrystusa, Kościół dokładnie określił istotne obrzędy sakramentów będące znakami łaski Bożej i otoczył je szeregiem innych obrzędów, które uzmysławiają skutki sakramentów i ułatwiają godne przygotowanie się na przyjęcie łaski Bożej.

$\mathrm{Na}$ wzór sakramentów ustanowił Kościól błogosławieństwa, przez które uświęca życie i pracę odkupionego człowieka, oraz przedmioty, którymi się on posługuje.

Gdy chrześcijanin dobiegnie do kresu swojej ziemskiej wędrówki, Kościół wspiera go w ostatniej walce, a potem wśród liturgicznych modlitw składa do ziemi jego ciało, jak ziarno, z którego ma wyrosnąc nowe życie.

Modlitwy i obrzędy związane z udzielaniem sakramentów i błogosławieństw oraz $\mathrm{z}$ pogrzebem katolickim zawiera księga, która się nazywa rytuałem.

Ksiegga ta, podobnie jak cała liturgia rzymsko-katolicka przechodzi obecnie odnowę.

Pod tchnieniem Ducha Świętego w Kościele obudziło się u wiernych żywe pragnienie czynnego uczestniczenia w liturgii Koścłoła. Aby to umożliwić Stolica Apostolska pozwoliła na szersze uwzględnienie języków krajowych w obrzędach rytuału. W latach powojennych wiele krajów katolickich otrzymało rytuały dwujęzyczne. Rytuał taki przygotowano również w Polsce. Został on zatwierdzony przez Swiętą Kongregację Obrzędów dnia 23 października 1959, a w Niedzielę Wielkanocną 14. IV. 1963 roku wchodzi w użycie we wszystkich diecezjach Polski.

\section{TREŚĆ NOWEGO RYTUAEU}

Nowy rytuał obejmuje obrzędy Sakramentów oraz sakramentaliów z nimi związanych, kilkadziesiąt błogosławieństw oraz obrzędy pogrzebowe. Ze względu na trwającą obecnie ogólną reformę liturgii nie opracowano na razłe obrzędów związanych z rokiem kościelnym oraz błogosławieństw rzadziej używanych. $\mathrm{Z}$ pośród dwujezycznych rytuałów zatwierdzonych po wojnie, nowy rytual Polski jest jednak najobszerniejszy. 


\section{JEZZYK POLSKI W RYTUALE}

Aby umożliwić wiernym świadomy i czynny udział w obrzędach liturgicznych Stolica Apostolska pozwoliła na używanie w rytuale języka polskiego z wyjątkiem formuł sakramentalnych, egzorcyzmów oraz kilku innych modlitw. Przez zachowanie języka lacińskiego w istotnych formułach sakramentalnych zaznacza się nasza przynależność do obrządkı rzymskiego Kościoła Katolickiego, do którego należymy od zarania naszego chrześcijaństwa. Natomiast wprowadzenie języka polskiego do większości obrzędów rytuału ułatwi wszystkim uczestn kom zrozumienie znaczenia modlitw i obrzędów odprawianych przez kapłana oraz należyte przygotowanie duszy na działanie łaski sakramentalnej.

Sprawowanie czynności liturgicznych w języku żywym jest dla naszego pokolen:a nowością. Nie jest to jednak nowość w życiu Kośc'oła. Większość formuł liturgicznych, którymi się posługujemy powstała w czasach, gdy język łaciński był językiem żywym, rozumianym przez wszystkich uczestników liturgii. Jest to zatem powrót do pierwotnych zwyczajów Kościola.

\section{WZBOGACENIE OBRZĘDÓW}

Niektóre obrzędy rytuału zostały na nowo uporządkowane i wzbogacone.

Jeżeli zajdzie potrzeba udzielania choremu od razu trzech sakramentów, to Namaszczenie Chorych zostanie udzielone po Sakramencie Pokuty a przed Komunią świętą lub wiatykiem, ponieważ Namaszczenie Chorych gładzi pozostałości grzechu. Przed udzieleniem Wiatyku chory będzie odnawial przymierze Chrztu świętego.

Wzbogacono również obrzędy Sakramentu Małżeństwa, aby podkreślić cele katolickiego malżeństwa oraz czynną rolę nowożeńców, którzy sobie tego Sakramentu udzielają.

W oparciu o stare rytuały polsk e zmieniono teksty błogosławieństwa nowozaślubionej małżonki oraz błogosławieństwa matki zwanego wywodem.

Uzyskaliśmy również zatwierdzenie kilku błogosławieństw nie znanych rytuałowi rzymskiemu, a potrzebnych w naszym życiu religijnym.

\section{CZYNNY UDZIAE WIERNYCH}

Język polski został wprowadzony do rytuału nie tylko dlatego, aby wierni mogli rozumieć formuly liturgiczne, lecz także dlatego, aby mogli modlić się z Kościolem.

Nowy rytuał wielokrotnie zaznacza, że wszyscy obecni mają odpowiadać kapłanowi, wspólnie odmawiać modlitwy i śpiewać. W śpiew:e hymnów i psalmów zachodzących w rytuale zàsze powinni brać udział uczestniczący w obrzędzie. psalmy od wieków są wzorem modlitwy chrześcijańskiej, ponieważ powstały pod natchnieniem Ducha Sw'ętego i były odmawiane przez P. Jezusa i Jego Matkę. Warto wspomnieć, że najstarsze zabytki literatury polskiej to psałterze, z których kart modlili się nasi przodkowie. Trzeba, aby te natchnione pieśni wróciły na nasze usta. Dlatego śpiewajmy wspólnie psalmy w czasie czynności liturgicznych i poza nimi. Wszystkie psalmy zawarte w rytuale można śpiewać także w czasie nabożeństw, adoracji i procesji.

\section{ROZPORZĄDZENIA WYKONAWCZE}

Aby przywrócić czynny udział wiernych w obrzędach rytuału musimy włóżć pewien wysiłek.

1. Wzywamy duszpasterzy, aby często wyjaśniali znaczen'e świętych obrzędów w kazaniach, katechizacji i w czasie sprawowania świętych dbrzędów. 
2. Wzywamy kapłanów, organistów, dyrygentów chórów kościelnych i katechetów, aby przystąpili do systematycznego uczenia śpiewów zawartych w rytuale. Chóry kościelne powinny doskonale znać wszystkie śpiewy rytuału i wzorowo je wykonywać. Są to o wiele ważniejsze części służby Bożej niż rozmaite śpiewy okolicznościowe, którym poświęca się nieraz wiele starania. Spodziewamy się, że chóry kościelne prędko opanuja spiewy zawarte w rytuale i pomogą duszpasterzom w ich upowszechnieniu

3. W ramach katechizacji należy stale uczyć poprawnego śpiewania melodii zawartych w rytuale, tak, aby młodzież kończąca katechizację stopnia podstawowego umiała dobrze odpowiadać na wezwania kapłana oraz wprawnie wykonywała śpiewy związane z udzielaniem Sakramentów oraz pogrzebom dorosłych i dzieci. Jeżeli ta praca będzie prowadzona systematycznie, w ciągu kilku lat osiągniemy dużą znajomość tych śpiewów wśród wiernych.

4. W obrzędach rytuału mają uczestniczyć wszyscy wierni, a nie tylko wybrane grupy, Dlatego należy wszystkich wiernych uczyć śpiewania melodii zawartych $\mathrm{w}$ rytuale. W pierwszych latach trzeba będzie większego wysiłku duszpasterzy i muzyków kościelnych. Z czasem śpiewy te będą przechodziły na nastepne pokolenia droga tradycji. Wzywamy wiernych. aby ze swej strony okazali dobrą wolę i chętnie uczyli się tych śpiewów, przez które wykonują swoje „królewskie kapłaństwo" wynikające z charakteru Chrztu świętego.

5. Aby udostępnić wiernym teksty świętych obrzędów należy przedrukować wyjątki z rytuału w modlitewnikach i śpiewnikach, po uzyskaniu zgody Konferencji Plenarnej Episkopatu.

\title{
ZAKOŃCZENIE
}

Drodzy Bracia i Siostry! Na pierwszej sesji 2 Soboru Watykańskiego Biskupi omówili i ustalili zasady odnowienia liturgii. $\mathrm{Z}$ zadowoleniem stwierdzamy, że nasz rytual został opracowany zgodnie $z$ duchem tych zasad i dlatego nasza praca nad wprowadzeniem go w życie będzie stanowiła czastke starań o odnowienje Kościoła Chrystusowego i dostosowanie form jego życia do naszych czasów.

$\mathrm{Na}$ tę pracę błogosławimy kapłanom, muzykom kościelnym i wszystkim wiernym dzieciom Kościoła świętego - w imię Ojca i Syna i Ducha Świętego.

\author{
KARDYNAE PRYMAS \\ oraz wszyscy \\ ARCYBISKUPI $i$ BISKUPI \\ Ordynariusze polscy
}

\section{SP. OPAT TEODOR NEVE OSB}

Dnia 27 marca 1963 przeszedł do wieczności Sp. O. Teodor Nève OSB opat św. Andrzeja koło Bruges w Belgii w 84 roku życia, 63 roku powolania zakonnego, 58 roku kapłaństwa i 51 roku opactwa.

O. Teodor Nève wstąpił do opactwa w Maredsous i stamtąd przeszedł do powsta iącego klasztoru św. Andrzeja. W latach 1908-1912 pełnił w tym klasztorze urząd przeora. W roku 1912 został mianowany pierwszym Opatem nowego klasztoru i nadał olbrzymi rozmach dziełom apostolskim. W roku 1910 Opactwo św. Andrzeja podjęło ewangelizację Katangi i obsługiwało cały wikariat apostolski podniesiony ostatnio 